\title{
THE EFFECT OF VEHICLES INTENSITY IN SUMBERSARI JEMBER REGENCY
}

\author{
Eva Kurniasari , Dinda Ayu Pramesty \\ Geography Education Study Program, University of Jember \\ E-mail: kurniasarieva2@gmail.com
}

Received:1October 2018/Accepted: 10 January 2019/Published online: 27 January 2019

\begin{abstract}
The main problem is vehicles very much owned by the public of Indonesia. One of transportation that is used population usefulness as a tool for mobility to a place that will be addressed, from rural to urban areas or vice versa. Community needs more triggers the movement of people from one place to another. Highway average - average be passed by a motorcycle and a car. Geography and transport have a very close relationship. The purpose of this study was to analyze the density of the vehicle in the sumbersari area of Kabupaten Jember. The method used is a survey using a sample area. The results showed that vehicle density most often occurs in the morning and evening.
\end{abstract}

Keywords: mobility, effective today, the volume of vehicles

\section{Introduction}

The transportation system is the link between the passengers, goods, infrastructure, and facilities that interact in the context of the movement of people or goods covered by an order, either natural or artificial. It studies the spatial linkages that connect with the space restrictions of origin, destination, extension and nature. 
Table 1 Developments Number of Vehicles based on Type of Vehicle

\begin{tabular}{lrrrrrrr}
\hline \multicolumn{1}{c}{ Type of Vehicle } & $\mathbf{2 0 0 7}$ & $\mathbf{2 0 0 8}$ & $\mathbf{2 0 0 9}$ & $\mathbf{2 0 1 0}$ & $\mathbf{2 0 1 1}$ & $\mathbf{2 0 1 2}$ & $\mathbf{2 0 1 3}$ \\
\hline & & & & & & & \\
Motorcycle & 31925 & 38345 & 41361 & 419.275 & 464362 & 302375 & 413461 \\
Jeep / Jeep & 113 & 163 & 267 & 3,522 & 3,775 & 2706 & 1682 \\
Sedan / Car & 243 & 231 & 472 & 6683 & 7,092 & 3,432 & 256 \\
Colt station / Colt station & 683 & 703 & 1947 & 15973 & 18666 & 12468 & 31947 \\
Truck / truck & 264 & 290 & 393 & 6651 & 6959 & 3,688 & 5,414 \\
Colt pick up / colt pick up & 293 & 399 & 606 & 6004 & 6467 & 4,361 & 8489 \\
Bus / Bus & 464 & 503 & 156 & 449 & 490 & 351 & 465 \\
Ambulance / Ambulance & 20 & 13 & 2 & 45 & 47 & 53 & 9 \\
Roda 3 / Pedicab & 0 & 89 & 74 & 504 & 790 & 450 & 714 \\
\hline Total & 34005 & 40736 & 45278 & 459106 & 508648 & 329884 & 462437 \\
\hline
\end{tabular}

Based on police records Resort Jember, 2007 - 2013

The above table shows the development of the number of vehicles from year to year in Jember. The number of vehicles in 2012 decreased quite a lot, but in the next year ie in 2013 the number of vehicles increased again as many as 413461 . The dominant type of vehicle is a motorcycle increased. Location of Jember as provincial roads cause many vehicles that go into Jember, both of Banyuwangi, Bondowoso, and Lumajang.

Employment is causing increasing urbanization. The rapid urbanization is causing various problems one of which is the problem of transportation. Transportation problems evident that traffic jams. Communities often do pekerjaanpulang activity went from villages to cities has the vehicle speed and valume vehicles is growing more and more. People are increasingly bervariari model of the work being done for the progress of the industry today.

More and more workers the longer the worker meets the road to reach the workplace. Over time the movement of people getting lower and lower because urban land is expensive, so the settlement moved to the suburbs. This situation affects the mobility of people farther and farther from the city center. Colleges began to appear in the city center are also triggered the number of people who filled the street. The tendency of increasingly fierce competition in the future lead to continuing education such as courses, training, education, part-time degree becomes a necessity for someone who has worked. This trend is causing additional movement to the city center, where the training center is located. 
The more the volume of the vehicle causing various problems such as congestion. This congestion can hinder and disrupt community activities. Bottlenecks can slow the economy. Congestion is also usually caused by inadequate road capacity so that arose congestion.

\section{Methods}

This type of research is in the form of a survey. Tika (1997) says that "The survey is a method of research that aims to collect large amounts of data in the form of variables, units or individuals at the same time, the data collected through individual or certain physical samples with the aim to generalize about what is being investigated. Variables collected can be physically and socially ". The study was conducted at the arterial road Jember based Letjen DI Panjaitan Sumbersari. Not all roads are to be observed, only one-way street leading to the town of Jember.

\subsection{Data collection technique}

The data collection technique used is the technique obesevasi. Observation is an activity undertaken in the form of a field survey or go directly to the place of research with observation and recording of a phenomenon that exists in the field. Data collection techniques that are used in addition to observation of documentation. Data can also be a photo documentation. Studies conducted to complete documentation of data to analyze.

\subsection{Technique of Analysis}

Data analysis techniques used in studying the phenomenon of geography is descriptive analysis techniques. Descriptive analysis aims to provide a description of the subject of research based on data from variables derived from a group of subjects studied and is not intended to test the hypothesis.

\section{Results and Discussion}

Jember geographically located at the position 6027'29 "s / d 7014'35" BT and 7059'6 "s / d 8033'56" LS-shaped canyon fertile plains in the South and Central parts, surrounded by mountains that extends along the boundary. North and East as well as the Indonesian Ocean along the South boundary with the Nusabarong Island is the only island in the district of Jember. The strategic location because it is located 
between Surabaya and Bali crossroads, so that progress rapidly and become a barometer of economic growth in East Java East region.

As Autonomous Region, Jember have territorial boundaries, area, economic capacity, potential of the region, socio-political and socio-cultural and human resources. Thus the objective conditions that can reveal the characteristics of natural resources, commodities produced, livelihoods, economic and social circumstances and culture

The following table is intensity calculation data of vehicles.

Table 2 Intensity of Vehicles in the Morninng

Vehicles intensity (06:00 to 7:00 pm)

\begin{tabular}{|c|c|c|c|c|c|c|c|c|c|c|c|c|}
\hline date & Car & $\begin{array}{c}\text { pick } \\
\text { Up }\end{array}$ & Bus & Truck & Box & Motorcycle & Tosa & Bike & Gojek & line & Taxi & pedicab \\
\hline 1 & 330 & 9 & 2 & 2 & 6 & 1905 & 2 & 17 & 46 & 20 & 1 & 20 \\
\hline 2 & 279 & 6 & 2 & 4 & 3 & 2050 & 3 & 20 & 40 & 34 & 11 & 22 \\
\hline 3 & 122 & 10 & 1 & 11 & 1 & 1900 & 1 & 18 & 15 & 7 & 5 & 21 \\
\hline 4 & 328 & 6 & 2 & 3 & 1 & 1846 & 2 & 15 & 51 & 11 & 4 & 19 \\
\hline 5 & 274 & 7 & 3 & 6 & 6 & 1761 & 1 & 27 & 31 & 12 & 5 & 36 \\
\hline 6 & 283 & 8 & 1 & 5 & 2 & 1972 & 1 & 15 & 39 & 8 & 4 & 40 \\
\hline 7 & 309 & 9 & 1 & 6 & 3 & 2222 & 2 & 18 & 40 & 9 & 3 & 17 \\
\hline \multicolumn{13}{|c|}{7 a.m. to $08: 00 \mathrm{pm}$} \\
\hline date & Car & $\begin{array}{c}\text { pick } \\
\text { Up }\end{array}$ & Bus & Truck & Box & Motorcycle & Tosa & Bike & Gojek & line & Taxi & pedicab \\
\hline 1 & 455 & 15 & 0 & 1 & 4 & 1957 & 1 & 15 & 50 & 10 & 2 & 25 \\
\hline 2 & 367 & 10 & 2 & 1 & 4 & 1606 & 0 & 20 & 56 & 12 & 5 & 25 \\
\hline 3 & 169 & 13 & 2 & 1 & 6 & 1500 & 3 & 23 & 12 & 6 & 5 & 30 \\
\hline 4 & 374 & 15 & 4 & 1 & 6 & 1413 & 0 & 15 & 38 & 9 & 7 & 19 \\
\hline 5 & 280 & 11 & 2 & 2 & 9 & 1371 & 1 & 17 & 34 & 10 & 4 & 22 \\
\hline 6 & 304 & 10 & 0 & 1 & 2 & 1762 & 2 & 10 & 38 & 12 & 3 & 27 \\
\hline 7 & 315 & 15 & 1 & 4 & 3 & 1300 & 1 & 15 & 31 & 14 & 7 & 18 \\
\hline
\end{tabular}


The above table shows the number of vehicles heading Jember city passing through the area of research. The average number of vehicles has increased the hours of 06:00 to 07:00 $\mathrm{pm}$. The dominant types of vehicles are motorcycles as many as 2222 vehicles, while car as much as 330 vehicles on hours 7:00 to 08:00 pm. In accordance with the discoveries made by Firmansyah (2012), which explained thattraffic at the time of greatest current level / peak is at 6:00 a.m. to 8:00 pm. Events that often cause traffic congestion in the morning due yatu research location close to SMAN 1 Jember, so that when the day of many students through this area either by private vehicle or public transportation.

Table 3 Volume of Vehicles on the Day (11:30 to 12:30 WIB)

Volume of Vehicles (11:30 to 12:30 WIB)

\begin{tabular}{ccccccccccccc}
\hline date & Car & $\begin{array}{c}\text { pick } \\
\text { Up }\end{array}$ & Bus & Truck & Box & Motorcycle & Tosa & Bike & Gojek & line & Taxi & pedicab \\
1 & 285 & 25 & 0 & 2 & 1 & 1200 & 1 & 3 & 36 & 7 & 1 & 9 \\
2 & 136 & 25 & 1 & 4 & 11 & 1265 & 1 & 9 & 36 & 14 & 1 & 6 \\
3 & 315 & 30 & 1 & 3 & 11 & 1032 & 2 & 9 & 37 & 10 & 1 & 9 \\
4 & 330 & 15 & 1 & 4 & 10 & 1000 & 0 & 5 & 30 & 11 & 1 & 6 \\
5 & 380 & 20 & 1 & 3 & 9 & 1010 & 1 & 7 & 34 & 8 & 2 & 5 \\
6 & 321 & 10 & 0 & 3 & 8 & 960 & 2 & 5 & 28 & 7 & 1 & 8 \\
7 & 221 & 15 & 2 & 1 & 12 & 1112 & 1 & 2 & 31 & 14 & 1 & 2 \\
\hline
\end{tabular}

Source: Volume Vehicle Survey Results 2018

According to the table above the volume of vehicles during the day can be known that motor vehicle is dominated by private motorcycle riders with the highest number of 1265 vehicles per hour, on average, within a week the number of motorcyclists around 1083 private vehicles. The next motor vehicle is dominated private cars with the largest number of 380 cars per hour, with an average per week ranges from 284 cars per hour. Motor vehicle with a great third position is gojek with the largest number of 37 riders gojek, with an average of around 33 riders per week gojek per hour. Next there is a pick-up truck that has a number average week of 20 vehicles per hour. Public transport lin has an average week for up to 10 units per hour.

Boxcar had an average of one week up to 9 units per hour. Penggendara rickshaws have an average week for 6 units per hour. Pancal bicycle users also have an 
average week for 6 units per hour. Truck drivers have an average week by 3 units per hour. The next taxi driver, tosa motorists and bus riders have an average week by one unit per hour. It is proved in this way has a large volume of vehicles, so it is possible when children come home from school will occur congestion because many passing vehicles. In addition to the congestion that occurs is also caused by people who prefer to use private vehicles than people who use public transportation, so that more and more private vehicles that cause congestion.

Table 4 Volume of Vehicles in the Afternoon (17:30 to 19:30 WIB)

Volume of vehicles (17:30 to 18:30 WIB)

\begin{tabular}{|c|c|c|c|c|c|c|c|c|c|c|c|c|}
\hline date & Car & $\begin{array}{c}\text { pick } \\
\text { Up }\end{array}$ & Bus & Truck & Box & Motorcycle & Tosa & Bike & Gojek & line & Taxi & pedicab \\
\hline 1 & 300 & 10 & 2 & 2 & 5 & 945 & 0 & 3 & 23 & 3 & 1 & 4 \\
\hline 2 & 278 & 13 & 2 & 4 & 2 & 831 & 3 & 4 & 43 & 4 & 2 & 2 \\
\hline 3 & 604 & 12 & 0 & 4 & 2 & 1151 & 0 & 26 & 40 & 3 & 6 & 5 \\
\hline 4 & 353 & 20 & 0 & 4 & 6 & 1287 & 0 & 4 & 22 & 2 & 2 & 7 \\
\hline 5 & 298 & 21 & 0 & 1 & 4 & 1232 & 1 & 13 & 15 & 5 & 2 & 5 \\
\hline 6 & 368 & 20 & 1 & 2 & 2 & 1564 & 4 & 10 & 13 & 3 & 3 & 4 \\
\hline 7 & 309 & 15 & 1 & 6 & 3 & 1211 & 2 & 8 & 28 & 1 & 4 & 3 \\
\hline \multicolumn{13}{|c|}{$18: 30$ pm-.19.30 } \\
\hline date & Car & $\begin{array}{l}\text { pick } \\
\text { Up }\end{array}$ & Bus & Truck & Box & Motorcycle & Tosa & Bike & Gojek & line & Taxi & pedica \\
\hline 1 & 589 & 20 & 1 & 1 & 6 & 878 & 0 & 2 & 21 & 3 & 3 & 0 \\
\hline 2 & 604 & 17 & 2 & 1 & 4 & 694 & 0 & 4 & 44 & 3 & 2 & 0 \\
\hline 3 & 353 & 22 & 0 & 3 & 15 & 1732 & 0 & 9 & 17 & 1 & 4 & 1 \\
\hline 4 & 371 & 21 & 0 & 1 & 12 & 1322 & 0 & 3 & 25 & 3 & 2 & 3 \\
\hline 5 & 368 & 20 & 2 & 2 & 17 & 1371 & 4 & 10 & 16 & 2 & 2 & 4 \\
\hline 6 & 320 & 23 & 2 & 3 & 13 & 1145 & 0 & 9 & 20 & 4 & 1 & 2 \\
\hline 7 & 428 & 21 & 1 & 4 & 19 & 1252 & 2 & 5 & 43 & 6 & 4 & 4 \\
\hline
\end{tabular}

Source: Volume Vehicle Survey Results 2018

Based on the observation that we have done, the data can be seen that vehicle in the afternoon increase or decrease as the volume of vehicles in the afternoon at 17:30 till 
18:30 pm for 7 days. The volume of vehicles has increased, especially on cars and motorcycles. Based on the type of vehicle group showed that car traffic volume is higher than other vehicles, because the car has a total vehicle volume reached 2,510 units during that time.

Based on the type of vehicle group showed that the volume of motorcycles is higher than other vehicles, because motorcycles have a total volume reached 8221 units during that time. It is explained that most residents mostly private vehicles such as cars and motorcycles. At the time of the motorcycle more than in a car to avoid congestion. Trip most commonly occurs in the late afternoon where many people do move simultaneously at the same time.

Will affect the speed and volume of traffic density. The amount of volume on the road segment is used as a measure to determine the level of service. Currently the best size to see the level of service at a traffic condition is speed of operation and the ratio between volume and capacity on the two-lane or four-lane (Widodo, 2012).

public transportation, when waiting for public transportation a long, travel route public transportation is limited, walking distance to halt urban transport which is quite far away, the time between city transportation with one another (headway) long, the quality of the seating poor, the temperature in the city transportation kuran good, less kindly driver and conductor of city transport, less clean urban transport and seating is provided, the age of freight vehicles that are already old, the lack of a fleet of city transport in operation, the lack of availability of shelter and the size of the stop small (Frank, 2017).

Increasing the volume of vehicles that exploded causing serious congestion. This phenomenon causes the inhibition of the economic chain. The volume of vehicles that much is due to the many people who prefer to use private vehicles instead of private vehicles. They prefer prbadi vehicle for efficiency at the same time feel uncomfortable with public transport provided by the government. Solid hour traffic occurs in the morning, especially on Mondays. Vehicles from the direction towards the city of Banyuwangi, Jember, students who go to school, the workers who were heading to work merge into one, so that the volume of such vehicles can be exploded.

\section{Conclusion}

The intensity of the vehicle suffered variations. Average hours of Stem vehicle that morning with the number of motorcycles for approximately 2000 vehicles. This is due to the entire community activity occurs in the morning. Not too crowded during the 
day is not until 1000 units. Vehicles with congestion intensity relationship is very significant, because the intensity of the vehicle caused the delay speed while on the road. Relates also to the people who prefer private vehicles so that the vehicle pembludakan occur. Relations with the road capacity bottlenecks that if a vehicle is entering exceeds the capacity, it will cause congestion. Factors affecting the traffic density for the government to concentrate activities in the town of Jember.

\section{References}

Alhani et al. 2016 Suburban, IN, Pontianak, Case Road, and Sungai Raya. "Capacity Analysis of Road Traffic in Suburban Pontianak (Raya River Road Case In). Untan Civil Engineering Journal.

Bps. Jember 2015. In 2014 Bps Figures

Firmansyah, Deden Et Al. 2017 Analysis of a Traffic Jam Area (Case Study on The Street Lenteng Agung). Civil Engineering Journal. Vi (2). September. National Seminar On Civil Engineering, 2012. Ums Civil Engineering Program, University Of Pancasila Jakarta.

Frans, J. H Et Al. 2017. Transfer to Transport Public Transport Mode For Personal in Kupang. Civil Engineering Journal. Vi (2). September

Hand, D., \& Ning, U. 2010. Analysis Of Road Network Optimization Based Traffic Density In The Region Semarang Assisted Geographical Information Systems (Case Study Region Semarang Regency). Xv (2), 121-135.

Ifran, Ifsan Et Al. Performance 2015.Analisis Roads By Using Mkji Road Superintendent Check Agus Palembang : Tridinanti University. Pelembang.

Roads, P., Rukmini, Ra, \& Jepara, Kk 2017. Survey Current Density Traffic Intersection Reviews In Civil Engineering, 19-24.

Kamarwan, Ss 1997. Transportation Systems. Jakarta: Gunadarma.

Meyer, Jp, \& Allen, $\mathrm{Nj}$, 1984. Testing The "Side-Bet Theory" of Organizational Commitment: Some Methodological Considerations. Journal Of Applied Psychology, 69 (3), 372-378.

Sudjana, Nana. 1996. Statistical Methods. Bandung: Tarsito

Novalia, Cindy. 2016. Analysis And Solutions Traffic Congestion In Cities Roads (Case Study Jalan Imam Bonjol - Sisingamangaraja Street). Jrsdd, Iv (4): 153 -162

Pabundu Tika, Moh. 1997. Methods Of Geography. Jakarta: Pt Gramedia.

Pramoedya, Vishnu Et Al. 2016. Village of Ubud on The Threshold Gridlock. Journal of Tourism Destination. Iv (2). S1 Studies Program Of The Faculty Of Tourism Destinations Tourism Udayana University. 
Rizani, Ahmad, 2015. Evaluation of Performance Barriers Due Road Side (Case Study Road Soetoyo S Banjarmasin). Banjarmasin: Polytechnic Banjarmasin.

Rodrigue, Jean Paul. 2013. The Geography Of Transport Systems. Usa And Canada By Routledge 711 Third Avenue, New York, Ny

Susanto, Irwan Et Al. 2015. "Geospatial (Study Area: Central Bandung)." 5: 31-44.

Widodo, Revelation Et Al. 2012. Analysis of Volume, Speed, and Density Traffic Method Greenshields And Greenberg. Scientific Journal Semesta Teknika. Xv (2). 178184, November.

Wini, Mustikarani. 2016. Traffic Along The Way H Rais A Rahman (Sui Jawi) City Pontianak. : 143-55. 